
\title{
25 Research Square \\ Environmental Conditions, and Phenolic Compounds Potential in the Leaves of Vitis Tiliifolia
}

\author{
Humberto Mata.Alejandro \\ Universidad Veracruzana \\ María Elena Galindo-Tovar \\ Universidad Veracruzana
}

Otto Leyva-Ovalle

Universidad Veracruzana

Franco Famiani

Universita degli Studi di Perugia

Juan G Cruz-Castillo ( $\square$ jcruzcastillo@yahoo.com )

Universidad Autónoma Chapingo: Universidad Autonoma Chapingo https://orcid.org/0000-0002-86876235

\section{Research Article}

Keywords: wild Vitis, wild grapevines, MaxEnt, agroecological zoning, phenolic compounds

Posted Date: February 16th, 2021

DOl: https://doi.org/10.21203/rs.3.rs-183717/v1

License: (c) (1) This work is licensed under a Creative Commons Attribution 4.0 International License.

Read Full License 


\section{Abstract}

The wild vine Vitis tiliifolia is found in Mexico, Central América, and the Caribbean region. In the Veracruz State, in Mexico, grows in several municipalities and is used for nutritional and therapeutic purposes. The geographical distribution and environment where this Vitis grow has not been recorded. The leaves of $V$. tiliifolia are rich in phenolic compounds but potential areas with vines of high phenolic compounds are unknown. An agroecological zoning model to identify potential areas for the cultivation and development of this species was performed. Potential areas having wild vines of high phenolic compounds in the leaves were also determined. The model included 95 vine georeferences, obtained from four municipalities of central Veracruz. These were analyzed with maximum entropy modeling, mapped with ArcMap software, and correlated with the phenolic compounds found in leaves collected in the georeferenced areas. A zoning map was produced, with a potential area of $2763.72 \mathrm{~km}^{2}$, which included the states of San Luis Potosi, Hidalgo, Veracruz, Puebla, Oaxaca, and Chiapas. Agroclimatic variables of seasonality of temperature, precipitation, and organic matter in the soil were the most important for the development of this species. In the state of Veracruz, vines with the potential of high phenolic content were found in 29 municipalities with characteristics suitable for its cultivation. The highest phenolic content potential was found at altitudes between 1000 and 2000 meters in the municipalities of Huatusco and Cosautlán in the State of Veracruz.

\section{Introduction}

Mexico is a center of diversity for the Vitaceae family, home to 18 of the 60 species registered worldwide, in the states of Puebla, Estado de México, Michoacán, Morelos, Jalisco, Sinaloa, Chiapas, Oaxaca, Guerrero, Yucatán, and Veracruz. The most common species found are Vitis riparia, V. estivalis, V. rupestri, V. bourgenaea, $V$. berlandieri, V. biformis, and V. tiliifolia (Rzedowski and Calderón, 2005).

The wild Vitis are lianas or climbers that grow with natural tutors of different tree species. In the state of Veracruz grow at altitudes from 0 to $2300 \mathrm{~m}$, on mountain slopes, in gullies, and in some agroecosystems where coffee (Caffea arabica) and sugarcane (Saccharum officinarum) are the main crops (Cruz-Castillo et al., 2009). Wild Vitis species are non-timber forest resources; one, Vitis tiliifolia, adapts to different environments and is appreciated for its fruit, which is used for the elaboration of artisanal alcoholic beverages and has sometimes been overexploited (Galindo et al., 2019). Its leaves are prepared in infusions for therapeutic remedies, and the lianas are used for fencing and as an ornamental plant in gardens (Toledo et al., 1991, Cruz-Castillo et al., 2009). The devastation of forests and jungles has diminished the population of $V$. tiliifolia. Specific information, on the geographical distribution and dispersion of $V$. tiliifolia is scarce (Sabás-Chavez et al., 2018; Franco-Mora et al., 2008).

Using procedures of agroecological zoning, number of studies have been conducted for crops such as sunflower (Helianthus annuus) (Lopez et al., 2018), yucca (Manihot esculent Crantz) (Rivera-Hernandez et al., 2012), mango (Manguifera indica L.), and table grapes (Martínez et al., 2009). These studies have been useful for the development of specific cultural practices, use, and conservation programs. However, 
there are not agroecological zoning studies for wild grapes, including $V$. tiliifolia. There is a need for research on natural areas with agroecological potential, with favorable conditions for the conservation and sustainable use of $V$. tiliifolia considering nutraceutical compounds, such as trans-resveratrol, found in its leaves (Alejandro et al., 2020).

Researchers have reported on the antioxidant properties of the leaves of wild Vitis species, which are high in polyphenols (Tobar-Reyes et al., 2011), compounds which help to prevent aging and cancer, and reduce problems associated with the risk of cardiovascular diseases (De Porto et al., 2013). The skin of the fruit and the seeds of $V$. tiliifolia contain phenolic compounds as quercetin, catechins, epicatechin, and resveratrol (Jiménez et al., 2018; Juárez et al., 2017), and the leaves contain p-cumaric acid, kaempferol, gallic acid, catechins, quercetins, and resveratrol (Alejandro et al., 2020). The phenolic content in the leaves of wild Vitis vary according to genotype and environment (Franco-Mora et al., 2012).

The aims of this work were thus: (1) to identify areas with environmental conditions for the development of $V$. tiliifolia with high leaf phenolic content potential, and (2) to generate a map showing its possible distribution.

\section{Materials And Methods}

It was geo-referenced the presence of $V$. tiliifolia (Humb \& Bonpl. Ex Schult.) in the municipalities of Ixtaczoquitlán, Huatusco, Atlahuilco, and Cosautlán, in the central region of the state of Veracruz, Mexico. Huatusco and Cosautlán are located on the Neovolcanic Axis of Veracruz. Huatusco, at an altitude of 450 to $1900 \mathrm{~m}$, presents semi-warm humid environmental conditions with year-round rains, abundant in the summer. Rainfall is from 1100 to $1600 \mathrm{~mm}$ per year, with temperatures ranging from 16 to $26^{\circ} \mathrm{C}$. Cosautlán, at an altitude of 600 to 1500 m, has similar weather, with annual precipitation from 1900 to $2100 \mathrm{~mm}$ and temperatures from 18 to $22^{\circ} \mathrm{C}$. (INEGI, 2016). Atlahuilco, in the Sierra Madre del Sur at an altitude of 1760 to $2700 \mathrm{~m}$, has a humid temperate climate with abundant rains and a subhumid temperate climate with rains in summer. Rainfall is from 1100 to $2100 \mathrm{~mm}$, with temperatures from 14 to $18^{\circ} \mathrm{C}$. Ixtaczoquitlán lies at the convergence of the Neovolcanic Axis and the Sierra Madre del Sur, at an

altitude of 700 to $1700 \mathrm{~m}$. It has a warm humid climate, with abundant rains in summer. Annual rainfall is from 1900 to $2600 \mathrm{~mm}$, with temperatures from 18 to $24^{\circ} \mathrm{C}$. (INEGI, 2018).

Geographical data were collected for 95 wild $V$. Tiliifolia vines in the four mentioned municipalities using a Garmin GPS Model 010-01508-10. A potential distribution model of $V$. tiliifolia was developed for the state of Veracruz and for the Mexican country. In addition, using the leaf phenolic data of $V$. tiliifolia in Alejandro et al. (2020) that indicated 13 compounds, potential production areas of high phenolic content were also identified.

Zoning

To develop the distribution model of $V$. tiliifolia in the state of Veracruz, coordinates were recorded from three sampling points in each of the four municipalities described above, using a Garmin Etrex GPS, with 
vectorial layers at a scale of 1:250,000 (INEGI, 2018), complemented with bibliographic information on the natural phytogenetic resources of the four municipalities. The cartographic design used ArcMap 10.5 Madeira software. A potential agroecological zoning model for $V$. tiliifolia was also elaborated for the Mexican country. Maps were elaborated using nineteen climatic layers and one of topography (altitude), with a resolution of 30 seconds of arc, equivalent to $\approx 1 \mathrm{Km}^{2}$ at the equatorial plane. The data for cells at each layer included the environmental values of temperature, precipitation, and altitude (Hijmans et al., 2005). The layers were defined by the extreme coordinates of the territory of Mexico: $33^{\circ} \mathrm{N}, 14^{\circ} \mathrm{S},-86^{\circ} \mathrm{E}$, and $-119^{\circ} \mathrm{W}$. Nine layers of soil properties were used on a scale of 1:1,000,000 (Cruz-Cárdenas et al., 2014).

The MaxEnt software (Phillips and Dudík, 2008) was used to estimate the average probability for each environmental variable at the geographic coordinates of each occurrence of vines. To select the most important climatic characteristics, an initial run was made with the 29 environmental, orographic, and soil variables, followed by a second run eliminating information that did not contribute any agroecological information to the model (Soberón and Peterson, 2005). The agroecological zoning model was analyzed with the values of the area under the curve (AUC), where an AUC $>0.9$ based on the presence of $V$. tiliifolia was considered suitable (Phillips et al., 2006). A map was produced showing the capacity of discrimination of a presence (sensitivity) versus the capacity of discrimination of an absence (specificity) (Phillips et al., 2004). The color scale of the map shows the probability of coincidence of the ideal environmental conditions for cultivation. Precipitation in the wettest months, seasonality in the driest month, seasonality in precipitation, and altitude were chosen as the most important environmental variables for the logistic prediction model (Merow et al., 2013). The Jackknife statistical test in MaxEnt was used to calculate the relative agroecological importance of each variable (Sokal and Rohlf, 1995; Phillips et al., 2006).

Phenolic content potential and environmental conditions

To identify potential areas with the environmental conditions for the cultivation of $V$. tiliifolia with high leaf phenolic content, a partial least squares (PLS) regression analysis was performed, using the statistical program InfoStat ( Di Rienzo et al., 2017). The environmental data used were precipitation in the wettest months, seasonality in the driest month, seasonality in precipitation and altitude, and soil characteristics for the 95 in situ V. tiliifolia vines, obtained from the MaxEnt attribute table using the predictor variables of greatest contribution. The ex situ phenolic content was determined for mature leaves in six-year-old vines growing at the Autonomous University of Chapingo in Huatusco, Veracruz $\left(19^{\circ}\right.$ $08^{\prime} 48^{\prime \prime} \mathrm{N}, 96^{\circ} 57^{\prime} 00^{\prime \prime} \mathrm{W}$, altitude $1344 \mathrm{~m}$ ). Leaf samples from the municipalities of Huatusco, Ixtaczoquitlán, Cosautlán, and Atlahuilco were collected after flowering in June 2016 (spring). The determination of polyphenols was carried out with aqueous extraction. The 13 phenolic compounds used as data in the zoning were those reported by Alejandro, et al. (2020) in Table 2 (https://jast.modares.ac.ir/article-23-27802-en.html).

\section{Results}


The data collected in the municipalities of Ixtaczoquitlán, Huatusco, Atlahuilco, and Cosautlán showed that $V$. tiliifolia develops at altitudes ranging from 800 to $2300 \mathrm{~m}$ (Fig. 1). Different conditions for $V$. tiliifolia growth in several municipalities of the high mountain region were found (Fig. 2). Of the 29 climatic and pedological variables considered, 19 contributed $100 \%$ of the factors of agroecological importance. The contributions of different environmental variables to the agroecological zoning model are shown in Table 1. The most important were precipitation in the driest period (Bio14), with a $42.4 \%$ contribution; the elevation (DEM), with 22.7\%; organic matter (OM), with 9.7\%; precipitation in the wettest period (pp_humid), with $6.7 \%$, and seasonality of precipitation (Bio15), with $5.8 \%$. The AUC value of 0.998 was very close to 1 , indicating a good fit for the model. Most of the area identified by our model was located in the neotropical region, in the southern and southeastern Mexico, which is mountainous (Fig. 3). The zoning map developed for the Mexican country had six cumulative zone thresholds with agroecological potential for the development of $V$. tiliifolia, which include the states of San Luis Potosí, Hidalgo, Puebla, Oaxaca, Chiapas, and Veracruz (Fig. 3).

Table 1

Variables of agroecological importance for the cultivation of Vitis tiliifolia in Mexico: \% contribution to model

\begin{tabular}{|llllllll|}
\hline Temperature & $\%$ & Precipitation & $\%$ & Ground or Soil & $\%$ & Topography & $\%$ \\
\hline Bio 7 & 1.3 & Bio14 & 42.4 & OM & 14.1 & DEM & 22.7 \\
\hline & Bio15 & 5.8 & $\mathrm{~K}$ & 3.9 & \\
& pp_humid & 6.7 & $\mathrm{Na}$ & 1.6 & \\
& & & $\mathrm{pH}$ & 1.5 & \\
\hline
\end{tabular}

Phenolic content potential and environmental conditions

The variables Bio14 (precipitation in the driest period), elevation (DEM), OM (organic matter), pp_humid (precipitation in the wettest period), and Bio15 (seasonality of precipitation) were the most important for the 95 sites of vine sampled variables, and they were correlated with the metabolic compound content in a partial least squares (PLS) analysis (Fig. 4). (The data is supplied in the electronic supplementary material). Bio 14 was correlated mainly with catechin, resveratrol, and rutin content in the localities of Huatusco and Cosautlán, with elevations ranging from 1162 to 1900 m (Fig. 4). There were positive correlations between altitude (DEM) and organic matter (OM) with the phenolic compounds: quercetin, quercetin glucoside, quercetin galactose, caffeic acid, and epicatechin in the localities of Cosautlán and Melchor Ocampo, with elevations from 1162 to 1357 m (Fig. 4). 


\section{Discussion}

The wild grape vines referenced grew in climates typical of the seasonal tropical forests of the Neovolcanic Axis mountains and the Sierra Madre del Sur (Gentry, 1991; Schenitzer and Bonguers, 2002). In the four municipalities studied grew in diverse climates that include semi-humid with rain from summer to winter; semi-hot humid with summer rain; moderate temperature humid with summer rain; and moderate temperature sub-humid. The wild grape vines need tree structures to develop its canopy, and they grow during wet and dry seasons, unlike the trees, which stop growing in the dry season in tropical forests (Cai et al., 2009; Sánchez-Azofeifa et al., 2009; Van der Heijden et al., 2019).

The altitude was after the precipitation in the driest period (Bio14), the second most important variable in the agroecological zoning model model (Table 1). The wild vines were located between 836 and $2300 \mathrm{~m}$, and there are reports at heights up to $2300 \mathrm{~m}$ (Rzedowski and Calderon, 2005). However, at this altitude their presence is reduced because of the low temperature. This characteristic of adaptive vulnerability may explain why these lianas are not abundant in temperate zones. Franco-Mora et al. (2012) found that $V$. tiliifolia develops better in warm zones.

Wild Vitis vines have been found to thrive in different types of soils, including Humic Andosols, Eutric Regosols, Lithosols, Haplic Phaeozems, and Rendzics (Luna-Gaona et al., 2010), and grow wild in acid soil with high organic matter content (Galindo-Tovar et al., 2019). These findings coincide with characteristic soils of the sampling area in the present study, which include Acrisols, Cambisols, Luvisols, Phaeozems, Redzics, and Vertisols. In Huatusco, Cosautlán, and Ixtaczoquitlán the soils were Cambisols, Luvisols, Phaeozems, and Humic Acrisols, which are characterized by superficial horizons, high clay content, considerable organic matter, and acidity. Luvisols have high clay content in the subsoil (FAO, 1999). In the municipality of Atlahuilco the soils were Luvisols and Redzics, the latter shallow with high organic matter content, very fertile, stony, resting on igneous rock, and rich in lime (INEGI, 2018).

Tropical forests and jungle soils are rich in OM (organic matter) content. Since most of the nitrogen, phosphorus, and sulfur come from the mineralization of the $\mathrm{OM}$, this high content increases vigor and foliar area (Swinchatt and Howell, 2004; Leeuwen et al., 2009) and fruit production in the vines (GalindoTovar et al., 2019). These areas have Humic Andosol, Eutric Regosol, Leptosol, and Haplic Phaoezem soils (INEGI, 2018).

V. tiliifolia was found in several states of Mexico: Guanajuato, Michoacán, Morelos, Estado de México, Hidalgo, Querétaro, Veracruz, Oaxaca, Tabasco, Chiapas, Guerrero, and Yucatán (Rzedowski and Calderón, 2005, 2007; Franco-Mora et al., 2007; Martínez et al., 2007; Luna-Gaona et al., 2010). Our findings add the states of San Luis Potosí and Puebla as potential areas for its cultivation (Fig. 4). These areas have environmental conditions similar to those in several central-southern states, with climates ranging from wet temperate with year-round rainfall, to sub-humid temperate with summer rainfall, to semi-warm with year-round rainfall, with variations of dry and warm humid climates. The physiographic characteristics of most of these include plateau, depression, mountains, and valleys, which correspond to the conditions cited by Rzedowski and Calderón (2005) for V. tiliifolia development. 
The availability of water is an important environmental factor, since moderate water stress induces the production of phenolic compounds such as stilbenes and catechins (Vezzulli et al., 2007; Kounduras et al., 2007; Chaves et al., 2010; Dulec et al., 2011). High availability of water, however, implies low phenolic and anthocyanin content in the plant (Van Leeuwent et al., 2004). The phenolic content is affected not only by latitude but also by altitude (Taquichiri et al., 2014); the plants produce phenolic compounds as a stress response to ultraviolet exposure on the leaves and fruit (Del Castillo et al., 2014; Mayer and Higed, 2012). Low phenolic content has been observed in elevations above $3000 \mathrm{~m}$ (Berli et al., 2013); it was lowest in Atlahuilco, at elevations from 1750 to $2358 \mathrm{~m}$. However, antioxidant content, including resveratrol, is greater at elevations between 1700 and $2000 \mathrm{~m}$, because the leaves are with greater exposure to sunlight, and there are more photoprotective pigments and proline (Berli et al., 2013), resulting in greater antioxidant capacity.

The organic matter covariable was closely related to higher phenol content potential in the leaves. Organic matter in the soil influences nitrogen absorption in the plant and the formation of aromatic amino acids such as phenylalanine, tyrosine, and malonates, and some of the amino acids from which the flavonoids are derived (Stalikas, 2007; Orsat and Routray, 2017). In localities of the municipality of Ixtaczoquitlán (I-CGr, I-Tux, I-CCh), with altitudes ranging between 800 and $1000 \mathrm{~m}$, and Huatusco Cerro Elotepec $(\mathrm{H}-\mathrm{CEl})$, organic matter was correlated with potential contents of the gallic acid, vanillic acid, chlorogenic acid, and vanillin in the leaves (Fig. 4). There were 29 municipalities in the state of Veracruz with high potential for growth and use of $V$. tiliifolia (Fig. 2). Cruz-Castillo et al. (2009) documented 21 Veracruz municipalities in which $V$. tiliifolia grows, and there are herbarium specimens in the Xalapa Institute of Ecology from 36 municipalities. The localities of Huatusco and Cosautlán, in the ecogeographic zone between 1000 and $2000 \mathrm{~m}$, had the highest potential for phenolic content. The distribution map also shows 15 municipalities in San Luis Potosí, 17 in Hidalgo, 64 Puebla, 513 in Oaxaca, and 24 in Chiapas (Fig. 3) with significant potential for the development of $V$. tiliifolia with a high phenolic content in its leaves that can be used for therapeutic and nutritional purposes.

\section{Conclusions}

The $V$. tiliifolia vines that develop at elevations between 1000 and $2000 \mathrm{~m}$ achieved the highest potential to produce phenolic compounds. In Veracruz, these elevations corresponded to the communities of Huatusco and Cosautlán. The map for Mexico showed that the areas with the best agroecological conditions were located in the Sierra Madre Oriental, the Neovolcanic Axis (San Luis Potosí, Hidalgo, Puebla, and Veracruz), the Sierra de Juárez (Oaxaca), the Sierra Madre del Sur (Oaxaca and Chiapas), and the Sierra de Chiapas (Chiapas), a total of 285 municipalities. The predictive variables that contributed most to the model were precipitation in the driest period, the elevation, organic matter, precipitation in the wettest period, and seasonality of precipitation.

\section{Declarations}

\section{Acknowledgements}


This work was partially supported by the Universidad Autónoma Chapingo, project 18014-C-87.

\section{Data are available, plant material can be exchange under certain scientific conditions}

\section{Compliance with ethical standards}

Conflict of interest The authors declare that they have not conflict of interest.

\section{References}

1. Alejandro MH, Cruz-Castillo JG, Galindo-Tovar ME, Guerra-Ramírez D, Famiani F, Leyva-Ovalle OR, Monribot-Villanueva JL, Guerrero-Analco JA (2020) Phenolic content and antioxidant capacity of infusions of leaves of Vitis tiliifolia (Humb \& Bonpl. Ex Schult.). J Agr Sci Technol 22 3: 829-836. https://jast.modares.ac.ir/article-23-27802-en.html

2. Berli FJ, Alonso R, Bressan-Smith R, Bottini R (2013) UV-B impars growth and gas exchange in grapevines grown in high altituda. Physiol Plant 149: 127-140. https://doi:10.1111/ppl12012

3. Cai ZQ, Schnitzer SA, Bongers F (2009) Seasonal differences in leaf-level physiology give lianas a competitive advantage over trees in a tropical forest. Oecologia 161: 25-33. https://doi:10.1007/s00442-009-1355-4

4. Chaves MH, Lopes CAM, Dantas LJA, et al (2010) Fenóis totais, atividade antioxidante e constituintes químicos de extratos de Anacardium occidentale L., Anacardiaceae. J Bras Farmacog 20:1 106-112. https://doi.org/10.1590/S0102-695X2010000100021

5. Coley-Smith JR, Verhoeff K, Jarvis WR (1980) The biology of Botrytis. Academic Press. 318. London. https://doi.org/10.1007/978-1-4020-2626-3_2

6. Cruz-Cardenas G, Lopez-Mata L, Ortiz-Solorio CA, Villaseñor JL, Ortíz E, Silva JT, Estarda-Godoy F (2014) Interpolation of Mexican soli propertie at a scale of 1: 1,000,000. Geoderma 213: 29-35. https://doi.org/10.1016/j.geoderma.2013.07.014

7. Cruz-Castillo JG, Franco-Mora O, Famiani F (2009) Presence and uses of wild grapevines in Central Veracruz, Mexico. J Int Sci Vig Vin 43: 77-81. https://doi:10.20870/oeno-one.2009.43.2.78

8. Da Porto C, Porretto E, Decorti D (2013) Comparison of ultrasound assisted extraction with conventional extraction methods of oil and polyphenols from grape (Vitis vinifera L.) seeds. Ultrason Sonochem 20: 1076-1080. https://doi.org/10.1016/j.ultsonch.2012.12.002

9. Deluc LG, Decendit A, Papastamoulis Y, Mérillon JM, Cushman JC, Cramer GR (2011) Water deficit increases stilbene metabolism in Cabernet Sauvignon berries. J Agr F Chem 59: 289-297. https://doi.org/10.1021/jf1024888

10. Del Castillo-Alonso MA, Diago MP, Monforte L, Tardaguila J, Martinez-Abaigar J, Nuñez- Olivera E (2014) Effects of UV exclusion of phenolic composition of leaves and berries of Vitis vinifera cv Graciano. J Sci Food Agr 95: 409-416. https://doi.org/10.1002/jsfa.6738 
11. FAO (1977) Agroecological zoning, General guide. Soil bulletin. Food and Agriculture Organization of the United Nations, Roma, Italia. http://www.fao.org/3/w2962s/w2962s00.htm Accessed 21 january 2020.

12. FAO (1999) World Reference Base for Soil Resources. Food and Agriculture Organization of the United Nations, Roma, Italia. http://www.fao.org/3/a-a0510s.pdf. Accessed 23 january 2020.

13. Franco-Mora O, Cortes-Samchez AA, Rodriguez-Landero AC, Cruz-Castillo JG, Perez JM, MaderoTamargo J (2007) Localización y usos de vides silvestres (Vitis spp) en el estado de Puebla, México. Ra Xihaim 4: 1 151-165. https://doi:10.35197/rx.04.01.2008.09.om

14. Franco-Mora, O, Morales-Rosales EJ, González-Huerta A, Cruz-Castillo JG (2008) Vegetative characterization of wild grapevines (Vitis spp.) native to Puebla, Mexico. Hortsci 43: 1991-1995. https://doi.org/10.21273/hortsci.43.7.1991

15. Franco-Mora O, Aguirre-Ortega S, González-Huerta A, Castañeda-Vildózola A, Morales-Rosales EJ, Pérez-López DJ (2012) Characterization of Vitis cinerea Engelm. ex Millardet fruits from the southern region of the State of Mexico. Gen Res Crop Evo 59: 1899-1906. https://doi.org/10.1007/s10722012-9908-5

16. Galindo-Tovar ME, Davila-Lezama MR, Galicia-Sánchez A, Olivares BE, Guerra-Ramírez D, AguilarRivera N, Hernández-Rodríguez G, Famiani F, Cruz-Castillo JG (2019) Artisanal alcoholic beverages made with Vitis tiliifolia grape in Mexico. Rev Chapingo Cienc Hort 25:3 169-183. https://doi.org/10.5154/r.rchsh.2018.12.023

17. Gentry AH (1991) The distribution and evolution of climbing plants. in Putz FE, Mooney HA (ed). The biology old vines. Cambridge Uni Press, Cambridge, UK. 3-49. https://doi:10.1017/cbo9780511897658.003

18. Hijmans RJ, Cameron SE, Parra JL, Jones PG, Jarvis A (2005) Very high-resolution interpolated climate surfaces for global land áreas. Int J Clim 25: 1965 1978. https://doi.org/10.1002/joc.1276

19. INEGI (2018) General aspects of the Mexican territory. Natural resources. Edaphology. http://mapserver.inegi.org.mx

20. Di Rienzo JA, Casanoves F, Balzarini MG, Gonzalez L, Tablada M, Robledo CW 2017. Grupo InfoStat, FCA, Universidad Nacional de Córdoba, Argentina. http://www.infostat.com.ar

21. Jiménez M, Juárez N, Jiménez VM, Monribot VJL, Guerrero AJA (2018) Phenolic compounds and antioxidant activity of wild grape (Vitis tiliifolia). Ita J Food Sci 30: 128-143. https://doi.org/10.14674/IJFS-975

22. Juárez TN, Jiménez FV, Guerrero AJA, Monribot VJL, Jiménez FM (2017) Characterization of oil and flour obtained from wild grape seed (Vitis tiliifolia). R Mex Cienc Agr 8: 1113-1126. https://doi.org/10.29312/remexca.v8i5.112

23. Kounduras S, Hatzidimitrou E, Karamolegkoun M, Dimopoulou E, Kallithraka S, Tsialtas JT, Zioziou E, Kotseridis NY (2009) Irrigation and Rooststoc effects on the phenolic concentration and aroma potential of Vitis vinifera L. Cavernet Suavignon grape. J Agri F Chem 57: 7805-7813. https://doi.org/10.1021/jf901063a 
24. Latorre BA, Rioja ME, Lillo C (2002) Effect of temperature on flower and berry infections caused by Botrytis cinerea on table grapes. Cienc Inv Agr 29: 145-151. https://doi: 10.7764/rcia.v29i3.407

25. López-Rocha E, Mireles-Arriga Al, Hernández-R J, Ruiz-Nieto JE, Rucoba-García A (2018) Potential areas for sunflower cultivation under rainfed conditions in Guanajuato, Mexico. Agro Mesoame 29 2: 305-314. https://doi:10.15517/ma.v29i2.29771

26. Luna-Gaona G, Cruz-Castillo JG, Pérez-Portilla E, Licona-Vargas A, Sánchez SM, Franco-Mora O (2010) Distribución geográfica y aprovechamiento de las uvas silvestres (Vitis spp.) de la región Totonaca en la Sierra Norte de Puebla. Geo Agr 45: 39-47. https://www.redalyc.org/articulo.oa? id $=75726134003$

27. Martínez FJL, Tijerina CL, Arteaga RR, Vázquez PMA, Becerril-Román AE (2007) Determination of agroclimatic zones for the production of mango (Mangifera indica "Manila") in Veracruz, Mexico. Inv Geo 63. http://www.redalyc.org/articulo.oa?id=56906303

28. Martínez DG, Márquez CA, Sánchez SE, Mendoza LMR, Navarro AC, Valenzuela RM (2009) Strategies to improve the competitive position of table grapes in Mexico; (Edic) Behavior of table grape cultivars in different agro-ecological zones. INIFAP, CIRN, CECH. Technical Book 6-30

29. Mayer $P$, Hideg $E$ (2012) Developmental stage is an important factor that determines the antioxidant responses of young and old grapevine leaves under UV irradiation in a green-house. Plant Physiol Biochem 50: 15-23. https://doi.org/10.1016/j.plaphy.2011.09.018

30. Mendoza L, Yánez K, Vivanco M, Melo R, Cotoras M (2013) Characterization of extracts from winery by-products with antifungal activity against Botrytis cinerea. Ind Crop Prod 43: 360-364. https://doi.org/10.1016/j.indcrop.2012.07.048

31. Merow C, Smith MJ, Silander JA (2013) A practical guide to MaxEnt for modeling species distributions: what it does, and why inputs and settings mater. Ecography 36 10: 1058-1069. https://doi.org/10.1111/j.1600-0587.2013.07872.x

32. Orsat V, Routray W (2017) Microwave-Assisted Extraction of Flavonoids. Water Extraction of Bioactive Compounds. From Plan Drug Develop 8: 221-224. https://doi 10.1016/B978-0-12-8093801.00008-5

33. Phillips SJ, Dudik M, Schapire RE (2004) A maximun entropy approach to species distribution modeling. In Proceedings of the twenty-first international conference on Machine learning 83: 655662. https://doi10.1145/1015330.1015412

34. Phillips SJ, Anderson RP, Schapire RE (2006) Maximun entropy modeling of species geographic distribuitions. Ecol Model 190 3: 231-259. https://doi.org/10.1016/j.ecolmodel.2005.03.026

35. Phillips SJ, Dudik M (2008) Modeling od species distributions with Maxent: new extensions and a comprehensive evaluation. Ecography 31 2: 161-175. https://doi.org/10.1111/j.09067590.2008.5203.x

36. Rivera-Hernández B, Aceves-Navarro LA, Juárez-López JF, Palma-López DJ, González-Mancillas, González-Jiménez V (2012) Agroecological zoning and potential yield estimation of cassava 
(Manihot esculenta Crantz) in the state of Tabasco, México. Avanc Inv Agrop 16 1: 29-47. http://www.redalyc.org/articulo.oa?id=83723442003

37. Rzedowski J, Calderon G (2005) Flora del Bajio y de Regiones adyacentes. Fasciculo 131. Vitacea. Inst Eco Patzcuaro, Michoacan. 31

38. Sabás-Chavez CC, Franco-Mora O, Castañeda-Vildózola A, Sánchez-Pale JR, Cruz-Castillo JG, (2018) An approach to the model for conservation of Central Mexico Native Grapevines, Nat Res Conserv Res 1. http://dx.doi.org/10.24294/nrcr.v1i4.212

39. Sánchez AGA, Castro C, Wright SJ, et al (2009) Differences in leaf traits, leaf internal structure, and spectral reflectance between two communities of lianas and trees: Implications for remote sensing in tropical environments. Rem Sens Environ 113 10: 2076-2088.

http://dx.doi.org/10.1016/j.rse.2009.05.013

40. Schnitzer SA, Bongers F (2002) The ecology of lianas and their role in forests. Trend Eco Evo 17: 223230. https://doi.org/10.1016/S0169-5347(02)02491-6

41. Schnitzer SA, Carson WP (2010) Lianas suppress tree regeneration and diversity in tree fall gaps. Eco Lett 13 7: 849-857. https://doi.org/10.1111/j.1461-0248.2010.01480.x

42. Soberon J, Peterson AT (2005) Interpretation of models of fundamental ecological niches and species distributional areas. Biodiv Inform 2: 1-10. https://doi.org/10.17161/bi.v2i0.4

43. Sokal RRF, Rohlf J (1995) Biometry: the principles and practice of statistics in biological research. New York: State University of New York at Stony Brook 887. https://doi 10.1126/science.167.3915.165

44. Stalikas CD (2007) Extraction, separation, and detection methods for phenolic acids and flavonoids. J Sepation Sci 30: 3268-3295. https://doi10.1002/jssc.200700261

45. Swinchatt J, Howel DG (2004) The Winemaker's dance: Exploring terroir in the Napa Valley. Berkeley: University of California Press.

46. Taquichiri M, Ayarde R, Gutierrez P, Bustos AS, Paredes C, Callisava JC, Peñarrieta JM (2014) High Levels of Resveratrol in grapes cultivared at high altitude valleys in Bolivia. Int J Fruit Sci 14 3: 311326. https://doi.org/10.1080/15538362.2013.819748

47. Toledo GJU, Corrales-García JJE, Muratalla-Lúa A (1991) Study of the agronomic characteristics for industrial purposes of the wild grapevine (Vitis tiliifolia) in the Balsas Region. Rev Chapingo 76: 7378

48. Tobar-Reyes JR, Franco-Mora O, Morales-Rosales EJ, Cruz-Castillo JG (2011) Phenols of pharmacological interest in wild vines (Vitis spp.) Of Mexico. Bol Latinoam Caribe Plants Med Arom 10: $167-172$

49. Van Leeuwen CF (2004) Influence of climate soli and cultivar on Terroir. Am J Viticult 55: 207-217

50. Van Leeuwen C, Tregoat O, Choné X, Bois B, Pernet D, Gaudillère JP, (2009) Vine water status is a key factor in grape ripening and vintage quality for red Bordeaux wine. How can it be assessed for vineyard management purposes?. J Int Sci Vigne Vin 43: 121-134. https://doi.org/10.20870/oenoone.2009.43.3.798 
51. Van der Heijden GMF, Powers JS, Schnitzer SA (2019) Data from: Effect of lianas on forest-level tree carbon accumulation does not differ between seasons: results from a liana removal experiment in Panama. J Eco 107: 1890-1900. https://doi.org/10.1111/1365-2745.13155

52. Vezzulli S, Buttilani P, Bavaresc L (2007) Stilbene-Synthasa Gene Experession After Aspergillus carbonarius Infection in Grapes. Am J Enology Viticult 58: 132-134

\section{Figures}

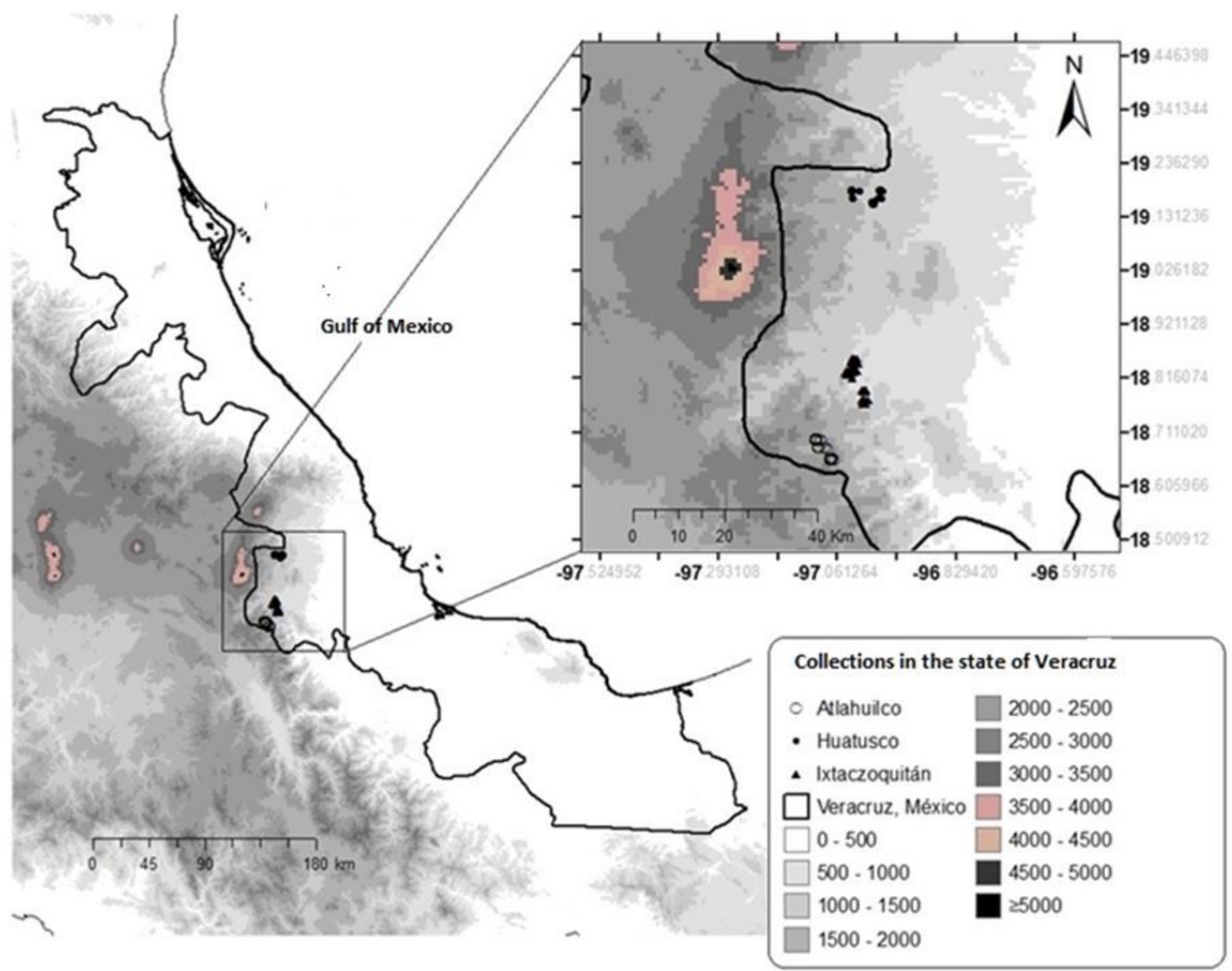

\section{Figure 1}

Geographic distribution of 96 collections of Vitis tiliifolia in central Veracruz Note: The designations employed and the presentation of the material on this map do not imply the expression of any opinion whatsoever on the part of Research Square concerning the legal status of any country, territory, city or area or of its authorities, or concerning the delimitation of its frontiers or boundaries. This map has been provided by the authors. 


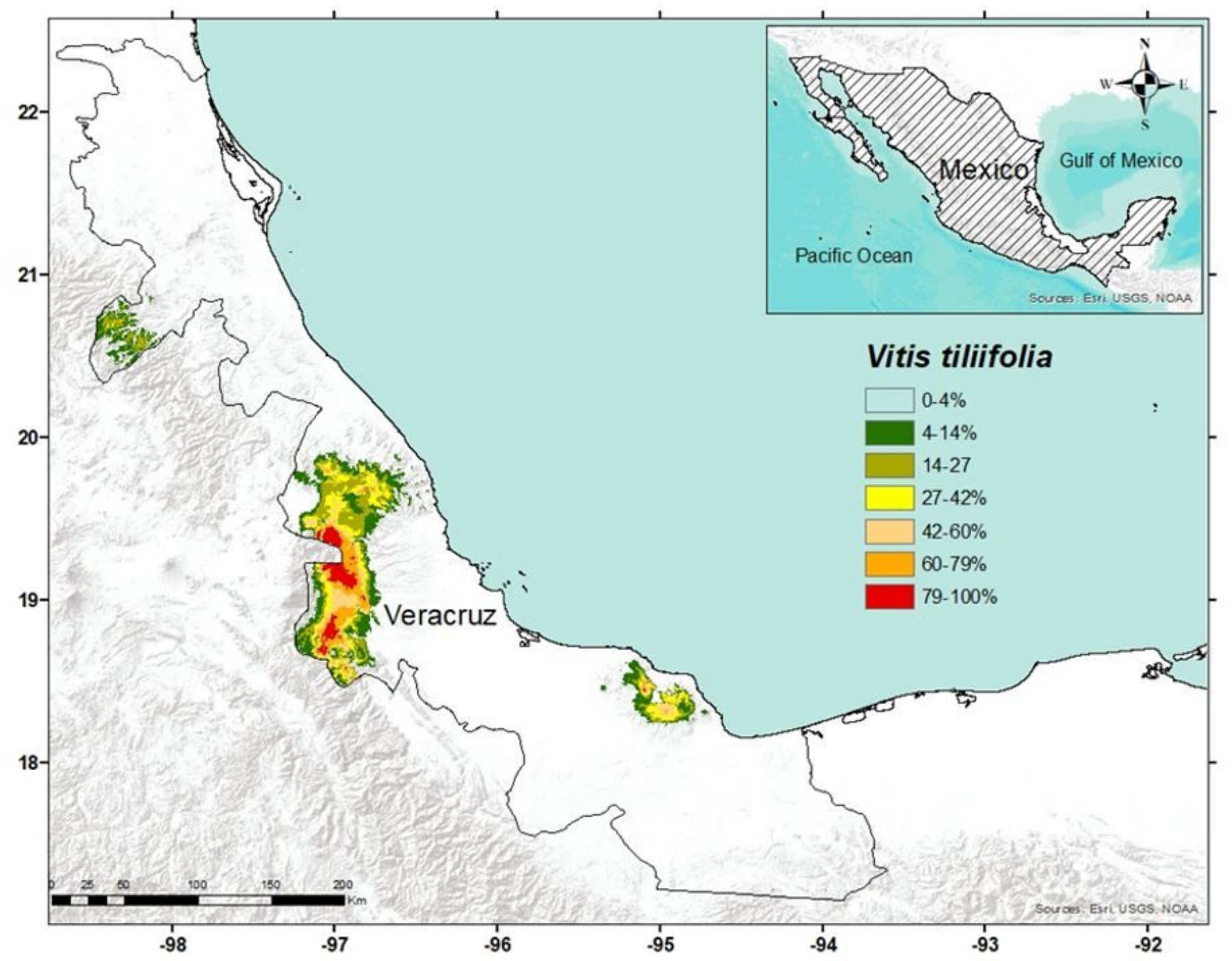

Figure 2

Agroecological zoning of Vitis tiliifolia for the state of Veracruz, using the maximum entropy model. The different colors show intensities (\%) of the V. tiliifolia presence. Note: The designations employed and the presentation of the material on this map do not imply the expression of any opinion whatsoever on the part of Research Square concerning the legal status of any country, territory, city or area or of its authorities, or concerning the delimitation of its frontiers or boundaries. This map has been provided by the authors. 


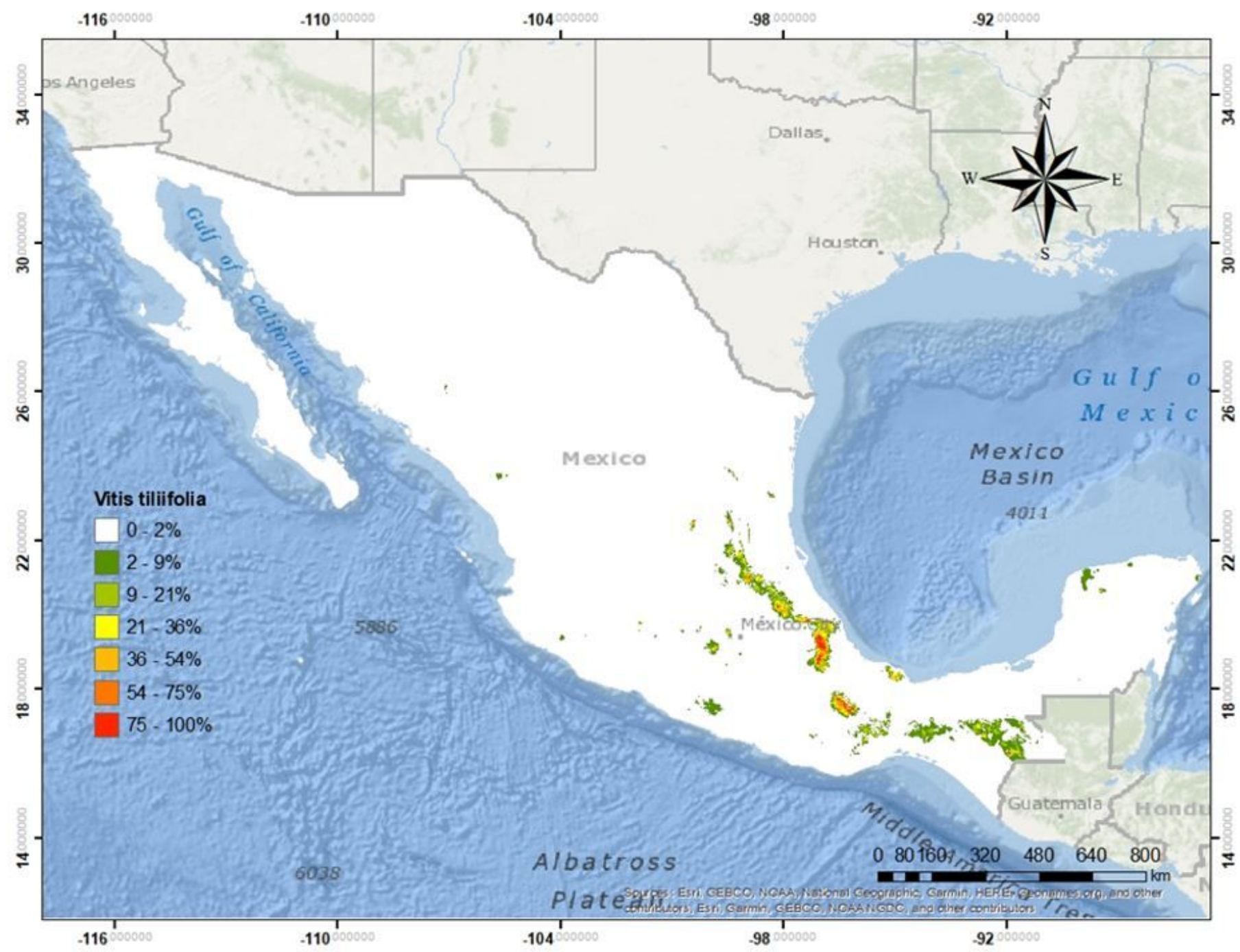

Figure 3

Agroecological zoning of Vitis tiliifolia in Mexico, using the maximum entropy model Note: The designations employed and the presentation of the material on this map do not imply the expression of any opinion whatsoever on the part of Research Square concerning the legal status of any country, territory, city or area or of its authorities, or concerning the delimitation of its frontiers or boundaries. This map has been provided by the authors. 


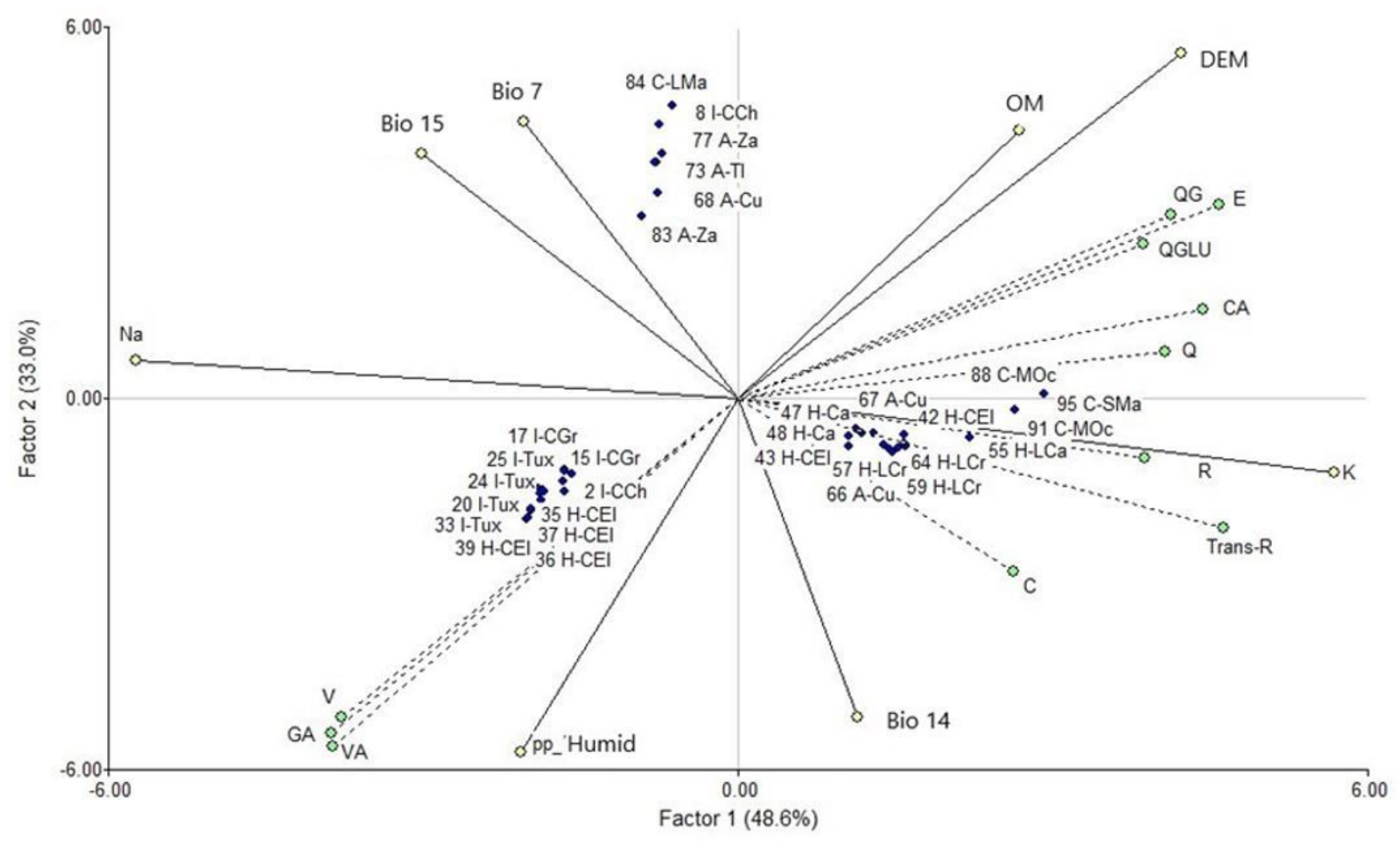

\section{Figure 4}

Biplot of correlations between the distribution of 96 collections of V. tiliifolia and five environmental variables. Bio7: Annual temperature oscillation ( $\left.{ }^{\circ} \mathrm{C}\right)$; Bio14: Precipitation in the driest period (mm); Bio15: Seasonality of precipitation ( $\mathrm{mm}$ ); pp_humid: precipitation in the wettest period $(\mathrm{mm})$; DEM: Digital elevation model (m); OM: Organic matter; $\mathrm{K}$ : potassium; $\mathrm{pH}$; Na: sodium. A matrix of 13 covariates of phenolic compounds (Alejandro et al., 2020, Table 2, in the electronic supplementary material) is included. Localities; I-Tux: Ixtaczoquitlán Tuxpanguillo; I-CGr: Ixtaczoquitlán Campo grande; I-CCH; Ixtaczoquitlán Campo Chico; H-Ca: Huatusco Las Cañadas; H-CEl: Huatusco Cerro Elotepec; H-LCr: Huatusco Las Cruces; A-Cu: Atlahuilco Cuahutlamanca; A-TI: Atlahuilco Tlalmorado; A-Za: Atlahuilco Zacamilola; C-SMa: Cosautlán Santa María; C-MOc: Cosautlán Melchor Ocampo; C-LMa: Cosautlán Las Maravillas Climatic Variables. Bio7: Annual temperature oscillation $\left({ }^{\circ} \mathrm{C}\right)$; Bio14: Precipitation in the driest period (mm); Bio15: Seasonality of precipitation ( $\mathrm{mm}$ ); pp_humid: precipitation in the wettest period (mm); DEM: Digital elevation model (m); OM: Organic matter; K: potassium; pH; Na: sodium. Phenolic compounds (Alejandro et al., 2020, Table 2, in the supplementary material). Trans-R: Trans-resveratrol; C: Catechin; GA: Gallic Acid; VA: Vanillic Acid; CHA: Chlorogenic Acid; CA: Caffeic Acid; E: Epicatechin; V: Vanillin; R: Rutin; QGLU: Quercetin Glucoside; QG: Quercetin Galactose; KF: Kaempferol-3-o-glucoside; Q: Quercetin. 